\title{
Knowledge Management in Support of Enterprise Risk Management
}

\author{
Eduardo Rodriguez, Telfer School of Management, University of Ottawa, Ottawa, Canada \\ and IQAnalytics Inc., Ottawa, Canada
}

John S. Edwards, Aston Business School, Birmingham, West Midlands, UK

\begin{abstract}
Risk management and knowledge management have so far been studied almost independently. The evolution of risk management to the holistic view of Enterprise Risk Management requires the destruction of barriers between organizational silos and the exchange and application of knowledge from different risk management areas. However, knowledge management has received little or no attention in risk management. This paper examines possible relationships between knowledge management constructs related to knowledge sharing, and two risk management concepts: perceived quality of risk control and perceived value of enterprise risk management. From a literature review, relationships with eight knowledge management variables covering people, process and technology aspects were hypothesised. A survey was administered to risk management employees in financial institutions. The results showed that the perceived quality of risk control is significantly associated with four knowledge management variables: perceived quality of risk knowledge sharing, perceived quality of communication among people, web channel functionality, and risk management information system functionality. However, the relationships of the knowledge management variables to the perceived value of enterprise risk management are not significant. We conclude that better knowledge management is associated with better risk control, but that more effort needs to be made to break down organizational silos in order to support true Enterprise Risk Management.
\end{abstract}

Keywords: Enterprise Risk Management, Financial Institutions, Information Systems, Knowledge Management Systems, Knowledge Sharing, Risk Control

\section{INTRODUCTION}

The separation between Knowledge Management (KM) and Risk Management (RM) is part of current organizational reality. The aim of this research is to study how KM concepts may help improve RM, and help to turn it into true Enterprise Risk Management (ERM). It builds on previous work on knowledgerelated constructs within RM (Rodriguez \& Edwards, 2010). In this article, we consider the relationships between $\mathrm{KM}$ variables related to knowledge sharing, and two RM variables: perceived quality of risk control (representing

DOI: 10.4018/ijkm.2014040104 
the operational level of RM) and perceived value of the ERM implementation (representing the strategic level). Crouhy, Galai, and Mark(2001) indicate the need for risk systems to control risk at individual and enterprise level.

This article begins with the identification of events that have affected the financial services industry and that indicate the need for better management of risk management knowledge. The succeeding sections introduce relevant concepts of risk management and knowledge management, present the research model that comprises eight hypotheses, and describe the analysis of the results of two regression models that were used to test them. The final sections discuss the findings and seek to interpret their meaning.

\section{The Context of Financial Services}

The financial crisis of recent years has raised many questions about the performance of financial institutions in response to adverse events. There are doubts about their capacity to execute the three knowledge components of the management of risk: use of models, use of technology and leveraging on people (Beasley, Bronson, \& Hancock, 2009; Champion, 2009; Taleb, Goldstein, \& Spitznagel, 2009).

Financial institutions are information and knowledge organizations (Fourie \& Shilawa, 2004). Risk is one of the principal business issues a financial institution must deal with. To manage risk "is frequently not a problem of a lack of information, but rather a lack of knowledge with which to interpret its meaning" (Marshall, Prusak, \& Shpilberg, 1996, p. 82). Knowledge reduces uncertainty (Nonaka, 1991) and therefore, knowledge reduces risk (Dickinson, 2001). However, it is not clear how knowledge is organized in, and provides support to, financial institutions in order to deal with uncertainty and risk.

The performance of financial institutions is affected by the management of wide risk exposure represented by an offer that includes more products and services than in the past. Financial institutions thus need to evolve from a risk management process based on silos of risk analysis towards Enterprise Risk Management (ERM) which is a dynamic risk management process across the company (Dickinson, 2001). To transform RM into ERM is a strategic step in managing risk, but is essentially good risk management practice (Lam, 2003) with an holistic view.

As $\mathrm{KM}$ also needs to take an holistic view of the organization (Edwards, 2009), it therefore seems reasonable to suppose that these two disciplines, when working together and complementing one another, can better handle the risks affecting financial organizations.

\section{THEORETICAL BACKGROUND}

This section presents concepts relating to managing risk (risk management processes, the differences between RM and ERM, and a description of the risk management system) and managing knowledge (knowledge management processes and knowledge management systems). It goes on to consider the small amount of existing work combining KM and RM.

\section{Risk Management in Financial Institutions}

For financial institutions, RM is "the overall process that a financial institution follows to define a business strategy, to identify the risks to which it is exposed, to quantify those risks and to understand and control the nature of the risks it faces" (Cumming \& Hirtle, 2001, p. 2 ) and a "collection of processes, people and systems aligned for the purpose of measuring, managing, monitoring, and controlling risk exposure." (Levine, 2004, p. 31).

The RM processes as described by Brown (2001) are shown in Table 1. Brown's categorization is based on types of action, presenting the activities involved in the RM processes by risk type. His model indicates that these actions are related to: managing the cost of risks; developing alerts; organizing measurement systems that can produce results that can be used by management 
Table 1. Risk management processes (Brown, 2001)

\begin{tabular}{|l|l|}
\hline \multicolumn{1}{|c|}{ RM Process } & \multicolumn{1}{c|}{ Description } \\
\hline $\begin{array}{l}\text { Risk } \\
\text { identification }\end{array}$ & $\begin{array}{l}\text { This process refers to the group of actions developed in the organization to classify and map } \\
\text { risks that can affect the organization in their current and expected business conditions }\end{array}$ \\
\hline $\begin{array}{l}\text { Risk } \\
\text { measurement }\end{array}$ & $\begin{array}{l}\text { Quantification and assessment of risk are important actions in RM; particularly, the capacity to } \\
\text { provide evaluation of the impact, frequency and severity of risks in the business operation. }\end{array}$ \\
\hline Risk monitoring & $\begin{array}{l}\text { These sets of actions represent the capacity to follow up on what has been designed for } \\
\text { managing risks. }\end{array}$ \\
\hline Risk control & $\begin{array}{l}\text { This represents the capacity to assure the adequacy of the RM actions, such as risk mitigation, } \\
\text { risk transfer and, in general, risk alignment to the policies and strategy. }\end{array}$ \\
\hline Risk application & $\begin{array}{l}\text { Policies and solutions for the business processes and the required conditions to keep risk } \\
\text { effects under control }\end{array}$ \\
\hline
\end{tabular}

to make decisions; and defining protection and solutions. The actions are carried out across the organization as a whole through a governance structure, controls and people development. A crucial element that Brown identifies is the need to support and develop the people involved, as only they can perform the RM actions and interpret the outcomes.

As mentioned above, the main difference between RM and ERM is in the enterprise strategic view of risk analysis for the whole organization as opposed to RM's "silo view". A more detailed list of the differences between RM and ERM is presented in Table 2.

\section{THE RISK MANAGEMENT INFORMATION SYSTEM (RMIS)}

Risk management processes require the support of a risk management information system (RMIS). RMISs need to have an open data

Table 2. Comparison between risk management and enterprise risk management. Differential attributes between Risk Management and Enterprise Risk Management (Meulbroek 2002; Lam 2003; Cumming and Hirtle 2001; Dickinson 2001).

\begin{tabular}{|l|l|}
\hline \multicolumn{1}{|c|}{ Risk Management (RM) } & \multicolumn{1}{c|}{ Enterprise Risk Management (ERM) } \\
\hline - Silo, individual view of risk & - Global, holistic view of risk \\
- Specific risk analysis & - Risk analysis across the organization \\
- Tactic orientation & - Strategic orientation \\
- Related to control and minimization & - Related to competitiveness \\
- Organization specific, department or business unit. & - Individuals, business units and the complete \\
Concentrated on business events & organization. Corporate view \\
- Disaggregated methods for risk analysis & - Aggregated methods \\
- Responsibility on the functional managers & - Governance/stakeholders responsibility \\
- Performance evaluation concentrated on the particular & - Risk performance evaluation enterprise wide and \\
problem solved & based on risk \\
- Protection of adverse financial effects of bad events. & - Organization stability protection. Decision making \\
Earnings volatility protection from the source & process based on risk \\
- Reactive & - Proactive \\
- Specific control on section or division expenditures & - Reviews and reduction of duplication of risk \\
- Individual risk analysis & management expenditures \\
- The priority is in the portfolio and individual sources & - Interdependent risk analysis \\
& - Priority can be in portfolio structure, assets \\
& modification, strategic movements \\
\hline
\end{tabular}


architecture based on Internet standards, and a flexible design to enable new RM processes to be supported by appropriate risk workflows (Levine, 2004). However, it has been argued that existing RMISs present more of a challenge to the development of ERM proper than a solution (Lee \& Lam, 2007).

McNally (2013) described the new framework for risk control proposed by COSO (the Committee of Sponsoring Organizations of the Treadway Commission) and indicates the need to manage information and communication as one of the key elements of the control system. Using relevant information, and internal and external communication capacity stand alongside developing means to evaluate and communicate deficiencies across the organization, and performing independent evaluations for processes, business units and areas in the organization structure. In summary, to integrate ERM with the management control systems in order to achieve strategic goals.

According to Hsu, Backhouse, and Silva (2013), there is limited research on understanding the role of IT as a support in operational risk management; in particular, IT can be a source of new risks. There is no clear road to understanding how managers decide to take a particular course of action in managing operational risk. Their findings from a case study of a financial organization show the value of knowledge sharing as a risk mitigant in operational risk management, and that organizational awareness of the importance of proper IT adoption is required in order to avoid new risks in the organization.

\section{Knowledge and Knowledge Management}

Wiig (2004, p. 335) indicates that "knowledge consists of truths and beliefs, perspectives and concepts, judgements and expectations, methodologies and know-how." There are many other definitions of knowledge. As respondents in our study were not presented with a definition of knowledge, but rather left to answer according to what they thought knowledge meant, we will not discuss its definition further here.

The same applies to knowledge management, which Wiig $(1997$, p. 3) defines as: “... the systematic, explicit and deliberate building, renewal, and application of knowledge to maximize an enterprise's knowledge-related effectiveness and returns from its knowledge assets." Again, we will not discuss the definition further here, but we do need to consider in more detail what $\mathrm{KM}$ consists of.

Heisig (2009) analysed no fewer than 160 KM frameworks, of which 117 included a list of processes or activities (p.9). In descending order of frequency, these were: share knowledge; create knowledge; use knowledge; store knowledge; identify knowledge; acquire knowledge. Ribière and Walter (2013) also found that knowledge sharing was the most common keyword in ten years of research papers on KM. We thus feel that it is reasonable to regard knowledge sharing as perhaps the most fundamental activity in KM.

Supporting the KM processes requires a Knowledge Management System(KMS). Alavi and Leidner (2001, p. 114) identified KMSs as the "kind of information systems applied to managing organizational knowledge." However, a KMS is not just technology-oriented; it also has to include the social and cultural components of KM (Davenport \& Prusak, 1998). Thus the KMS elements can be summarized as people interactions with both technology and processes (Edwards, 2009).

\section{Knowledge Management and Risk Management}

Very few articles attempt to combine KM and RM. In those that do, typically the approach has been more on identifying risks of knowledge management practice rather than applying KM to RM. Massingham (2010, p. 464) describes "knowledge risk management", the application of risk management principles, mainly risk scoring approaches, to manage risks relating to knowledge (especially its loss) in a case study 
from the Australian Department of Defence. Thus Massingham is looking more at how a KM metric can be an indicator of RM improvement than at how KM processes and systems can improve RM. Trkman and Desouza (2012) also use the phrase "knowledge risk management" to refer to the risks associated with knowledge management, for example that too much sharing of knowledge can adversely impact competitive advantage. They categorize these knowledge risks, and examine how these risks affect knowledge transfer. The other interaction between RM and KM in the literature is at a higher level. It builds on the consideration of $\mathrm{RM}$ as part of security in KM programs developed by Jennex and Zyngier (2007), to cover the governance of KM programs and the risk factors affecting a KM program (e.g. Zyngier, 2008; Zyngier \& Burstein, 2012; Zyngier \& Venkitachalam, 2011).

Most of the prior work on KM in financial institutions addresses either strategy (e.g. Shaw, Hall, Edwards, \& Baker, 2007; Spies, Clayton, \& Noormohammadian, 2005), both of which take the holistic view, or specific aspects such as customer knowledge (e.g. Värlander, 2008) or knowledge mapping (Fourie \& Shilawa, 2004) without explicit mention of risk management. A recent exception is the paper by Hsu et al. (2013) which identified knowledge sharing as a valuable factor for managing operational risk. This helps justify knowledge sharing as the area within KM whose influence on RM we shall study first.

\section{RESEARCH MODEL AND HYPOTHESES}

The hypotheses are expressed as the existence of relationships between independent variables describing knowledge sharing activities, and the dependent variables perceived quality of risk control, and perceived value of ERM implementation. The reason for using the two dependent variables is to capture the differentiation between RM practice, viewing separate risk areas risk by risk, and ERM's integral, holistic view of risk across the organization (Francis \& Paladino, 2008). We are measuring perceptions of performance of RM as a process, rather than measures of RM outcome performance.

The hypotheses (See Figure 1) are divided into three groups: people, process and technology (Edwards, 2009).

\section{People Hypotheses}

Three hypotheses were formulated regarding the effect of people variables: organizational capacity for work coordination, perceived quality of communication among people, and people's interaction for risk information system design:

- Organizational capacity for work coordination $(\boldsymbol{c w c})$ : Work coordination refers to the assignment of responsibilities and accountabilities between the participants in a business initiative. Ideally, organizational capacity for work coordination in risk management would be such that all the people who are involved in a risk process, project or assignment can achieve the goals by a synchronized development (Banham, 2004; Meulbroek, 2002). The hypotheses formulated were:

- H1a: Organizational capacity for work coordination is positively associated with the perceived quality of risk control;

- H1b: Organizational capacity for work coordination is positively associated with the perceived value of ERM implementation;

- Perceived quality of communication among people $(p q c)$ : Knowledge sharing and effective communication depends on the overlap and amalgamation of knowledge bases among people (Te'eni, 2006). The flow of information for risk knowledge in an ERM context needs communication capacity between the different groups in risk management (Uzzi \& Lancaster, 2003). A clear relationship between communication and risk knowledge sharing has not yet 
Figure 1. Research model

\section{Research Model Hypotheses}

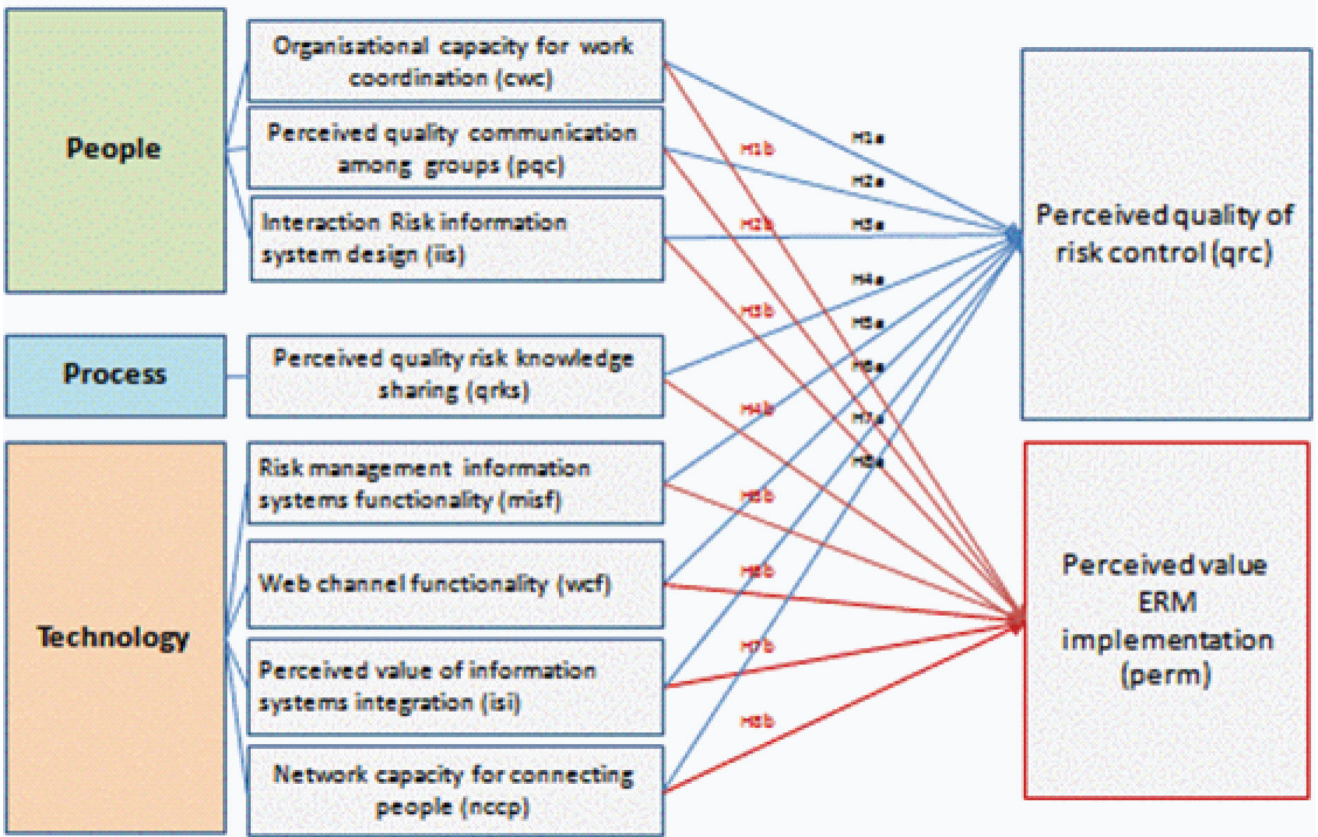

been identified. We chose the following "positive" hypotheses:

- H2a: The perceived quality of communication among people is positively associated with the perceived quality of risk control;

- H2b: The perceived quality of communication among people is positively associated with the perceived value of ERM implementation;

- People's interaction for risk information system design (iis): The design of an RMIS needs to encompass requirements from different risk areas, including both people interaction in each area, and the creation of collective risk knowledge which can contribute to the evolution of RM into ERM. Majchrzak, Beath, and Lim (2005) and Uchupalanan (2000) explain the value of collaboration in accomplishing information system design, facilitated learning management and support system design. The hypotheses were formulated as follows:

- H3a: People's interaction for risk information system design is positively associated with the perceived quality of risk control;

- H3b: People's interaction for risk information system design is positively associated with the perceived value of the ERM implementation.

\section{Process Hypothesis}

- $\quad$ Perceived quality of risk knowledge sharing (qrks): Shariq and Vendelo (2006, p. 833) state that: "When people solve complex problems, they bring knowledge and experience to the situation, and they engage in problem solving: they create, use, and share tacit knowledge." Improve- 
ment in knowledge sharing develops capacities inside the organization. RM might be influenced by attributes such as work satisfaction and capacity to share knowledge without a limitation on the number of people sharing. Organizational silos could adversely influence knowledge sharing, and business units can require assistance in knowing how to transfer their practical experiences to other units. In RM, the knowledge sharing process is not clearly identified. The hypotheses formulated were:

- H4a: The perceived quality of risk knowledge sharing is positively associated with the perceived quality of risk control;

- H4b: The perceived quality of risk knowledge sharing is positively associated with the perceived value of the ERM implementation.

\section{Technology Hypotheses}

The four KM variables in this group were: risk management information systems functionality, web channel functionality, perceived value of information systems integration, and quality of the network capacity for connecting people (in the organization):

- Risk management information systems functionality (misf): Functionality is identified as the capacity that the system has for answering the needs of the user (O'Brien, 1996). Functionality of information systems is an attribute that organizations as a whole and users look for in order to perform their activities. In general, the information systems design needs to provide the support required for RM/ERM, especially how to achieve goals of compliance with the new market conditions. Ideally, that functionality should support and facilitate knowledge sharing. Thus the functionality of a risk management information system might have influence on risk control and ERM. The following hypotheses were formulated:
- H5a: The risk management information system functionality is positively associated with the perceived quality of risk control;

- H5b: The risk management information system functionality is positively associated with the perceived value of ERM implementation;

- Web channel functionality (wcf): One specific knowledge sharing channel is the web channel used in order to improve communication capacity. Financial institutions have different technologies at their disposal to deliver their services to their internal and external customers. However, it seems that having independent intranets, putting emphasis on IT for knowledge sharing and having a reduced flow of KM processes through network systems all reduce knowledge sharing (Swan, Newell, Scarborough, \& Hislop, 1999). The issue is about the contribution of the use of web channel support to connect people, to support access to data, processes, applications and in general to the generation of consistency in all the dimensions of risk across the organization. Nevertheless, the hypotheses were again formulated "positively" as:

- H6a: The web channel functionality is positively associated with the perceived quality of risk control;

- H6b: The web channel functionality is positively associated with the perceived value of ERM implementation;

- Perceived value of information systems integration (isi): Complex, large organizations and multi-divisional businesses require the design of an enterprise architecture in order to support and co-ordinate access to data and systems (Hobday, Davies, \& Prencipe, 2005). Data should be in formats that are accessible and usable, and of sufficient quality to share and adopt in business processes. This research regards this transformation as a key part of KM: information systems have to be more efficient, effective, and integrated in order to 
help people to make more complex decisions. The hypotheses formulated were:

- H7a: The perceived value of information systems integration is positively associated with the perceived quality of risk control;

- H7b: The perceived value of information systems integration is positively associated with the perceived value of ERM implementation;

- Quality of the network capacity for connecting people (nccp): Effective KMS implementation needs the identification of stakeholders and the association of their different types of knowledge (Lehaney, Clarke, Coakes, \& Jack, 2004). Additionally, Earl (2001) introduces the networking capacity for connecting people in the organization as a success factor for KM implementation, often through a "Yellow Pages" knowledge directory approach. In risk control and ERM implementation, it could be an advantage to interrelate technological, methodological and business factors. Thus, the hypotheses formulated were:

- H8a: The quality of the network capacity for connecting people is positively associated with the perceived quality of risk control;

- H8b: The quality of the network capacity for connecting people is positively associated with the perceived value of the ERM implementation.

\section{RESEARCH METHODOLOGY}

The research takes a positivist approach: building a relationship model based on existing literature and on the experience of one of the authors in the sector, formulating hypotheses and testing them using statistical modelling (Babbie, 1998). The initial questions in the survey covered four demographic variables: risk management area of work, risk management process on which most time is spent, length of time in the current position and length of experience in risk management, followed by the actual item questions. The lack of previous studies combining KM and RM meant it was necessary to develop scales for the variables concerned that were appropriate for the respondents in the industry.

The survey was applied to a random sample of full-time employees in RM in financial institutions, in two phases. First, a sample of RM employees of financial services organizations' headquarters were contacted and (if willing) the questionnaire was administered face-to-face. This was used to test the questionnaire.

There were no substantive changes after the testing phase, only minor changes in the wording of some items, to avoid technical $\mathrm{KM}$ terms in the item formulation and assume greater literacy of RM people in computer and web related topics.

For the second phase, an electronic webbased questionnaire was constructed (Aaker, Day, \& Kumar, 1998). The final list of items is shown in Table 3 (space does not permit a full justification of each item here). An email invitation to participate in the survey was sent to members of the Professional Risk Managers International Association or the Risk Management Association who worked for financial institutions. Given this population's literacy in computer systems, the use of the web was not expected to bias the results.

The unit of analysis is thus an employee who is involved in RM activities in any RM process in a financial institution. All groups of $\mathrm{RM}$ employees are exposed to KM activities in a similar way given the centralization and corporate level decision processes that policies and strategy definition require in the sector.

The changes after the first phase were sufficiently small that it was judged reasonable to include the responses from this phase in the final analysis. The survey was thus distributed to a total of 620 full-time employees in RM in financial institutions. In total, 121 usable responses were received, giving a response rate of $19.5 \%, 19$ of the responses being face-to-face. The population was based world-wide, although more than 50\% were from North America. 
Table 3. Research variables and items used for their construction

\begin{tabular}{|c|c|c|}
\hline F Table Variable & $\begin{array}{l}\text { Items } \\
\text { (in the order in which they appeared on the survey) }\end{array}$ & Attributes and Reliabillity \\
\hline $\begin{array}{l}\text { Perceived value of } \\
\text { information systems } \\
\text { integration (isi) }\end{array}$ & $\begin{array}{l}\text { 1. The same standards are used } \\
\text { 2. A common data structure is used } \\
\text { 3. A common data-warehouse is used } \\
\text { 4. A common user interface is used } \\
\text { 5. A common report system is used } \\
\text { 6. A common application access is used }\end{array}$ & $\begin{array}{l}\text { Independent. Score index of } \\
\text { six items, each measured on } \\
\text { a 5-point scale (Cronbach's } \\
\text { alpha } 0.89 \text { ) }\end{array}$ \\
\hline $\begin{array}{l}\text { Organizational capacity } \\
\text { for work coordination } \\
\text { (cwc) }\end{array}$ & $\begin{array}{l}\text { 1. The organization encourages interdisciplinary work } \\
\text { 2. The organization encourages interdepartmental work } \\
\text { 3. There are good web based collaboration tools } \\
\text { 4. People are willing to work with multiple groups } \\
\text { 5. There are guiding principles for working with different groups } \\
\text { 6. There are standards for using collaboration tools }\end{array}$ & $\begin{array}{l}\text { Independent. Score index of } \\
\text { six items, each measured on } \\
\text { a 5-point scale (Cronbach's } \\
\text { alpha } 0.80 \text { ) }\end{array}$ \\
\hline $\begin{array}{l}\text { Perceived quality of } \\
\text { risk control (qre) }\end{array}$ & $\begin{array}{l}\text { 1. The risk mitigation tools are good } \\
\text { 2. The risk assessment process is good } \\
\text { 3. The risk transfer process is good } \\
\text { 4. The risk product evaluation is good } \\
\text { 5. The risk aggregation analysis is good }\end{array}$ & $\begin{array}{l}\text { Dependent. Score index } \\
\text { of five items, each } \\
\text { measured on a 5-point scale } \\
\text { (Cronbach's alpha } 0.86 \text { ) }\end{array}$ \\
\hline $\begin{array}{l}\text { Risk management } \\
\text { information systems } \\
\text { functionality (misf) }\end{array}$ & $\begin{array}{l}\text { 1. The systems provide support to the risk modeling process } \\
\text { 2. The systems provide access to experience in risk analysis } \\
\text { 3. The systems provide adequate data management support } \\
\text { 4. The systems provide capacity to improve work flow } \\
\text { 5. The systems provide capacity to work with multiple groups on a project }\end{array}$ & $\begin{array}{l}\text { Independent. Score } \\
\text { index of five items, each } \\
\text { measured on a 5-point scale } \\
\text { (Cronbach's alpha 0.88) }\end{array}$ \\
\hline $\begin{array}{l}\text { Perceived quality of } \\
\text { communication among } \\
\text { people (pqc) }\end{array}$ & $\begin{array}{l}\text { 1. The communication between the Risk Management groups is good } \\
\text { 2. The communication within my Risk Management group is good } \\
\text { 3. The communication environment fosters the interchange of different points of } \\
\text { view } \\
\text { 4. There is a good capacity to get conclusions easily during meetings } \\
\text { 5. The communication environment promotes team work }\end{array}$ & $\begin{array}{l}\text { Independent. Score } \\
\text { index of five items, each } \\
\text { measured on a 5-point scale } \\
\text { (Cronbach's alpha 0.88) }\end{array}$ \\
\hline $\begin{array}{l}\text { People's interaction for } \\
\text { risk information system } \\
\text { design(iis) }\end{array}$ & 1. Perceived quality of people interactions in the ERMIS design & $\begin{array}{l}\text { Independent. This is a } \\
\text { single item }\end{array}$ \\
\hline $\begin{array}{l}\text { Web channel } \\
\text { functionality (wcf) }\end{array}$ & $\begin{array}{l}\text { 1. The Risk Management Intranet provides access to collaboration tools } \\
\text { 2. The Risk Management Intranet provides access to all applications used in risk } \\
\text { management } \\
\text { 3. The Risk Management Intranet provides access to the proper data } \\
\text { 4. The Risk Management Intranet facilitates interaction in problem solving } \\
\text { process } \\
\text { 5. The Risk Management Intranet supports communication among risk } \\
\text { management people } \\
\text { 6. The Risk Management Intranet supports risk management controls }\end{array}$ & $\begin{array}{l}\text { Independent. Score index of } \\
\text { six items, each measured on } \\
\text { a 5-point scale (Cronbach's } \\
\text { alpha 0.92) }\end{array}$ \\
\hline $\begin{array}{l}\text { Perceived value of } \\
\text { ERM (perm) }\end{array}$ & $\begin{array}{l}\text { 1. ERM improves collaboration } \\
\text { 2. ERM promotes our experience sharing } \\
\text { 3. ERM reduces the number of times we reinvent the wheel } \\
\text { 4. ERM improves the quality of data } \\
\text { 5. ERM improves our interdisciplinary work } \\
\text { 6. ERM improves our interdepartmental work } \\
\text { 7. ERM improves our understanding of model results } \\
\text { 8. ERM improves our problem solving process } \\
\text { 9. ERM improves our capacity of mathematical modeling }\end{array}$ & $\begin{array}{l}\text { Dependent. Score index } \\
\text { of nine items, each } \\
\text { measured on a 5-point scale } \\
\text { (Cronbach's alpha 0.93) }\end{array}$ \\
\hline
\end{tabular}




\section{Measurement, Reliability and Validity}

All 53 substantive items in the survey were rated on the same Likert scale: 1 strongly disagree, 2 disagree, 3 neutral, 4 agree and 5 strongly agree. The Likert scale is used so that respondents evaluate their agreement with, preference for and attitude towards the statements for each item (Aaker et al., 1998). Values for the variables were then derived from the item scores. An important issue in aggregating item scores was not to assume that simple addition of the item scores (i.e. equal weight) would be appropriate (Alfares \& Duffuaa, 2008). For each observation, the original value $x$ was transformed to a new value given by z-score $(x-\mu) / \sigma$, , Bohrnstedt $\&$ Knoke, 1982) where $\mu$ is the mean and $\sigma$ the standard deviation. This transformation allows for the combination of items with a different mean and standard deviation.

Reliability was judged using internal reliability as measured by the Cronbach alpha coefficient, because the variables are built through items without previous scales. The cut-off value considered to be acceptable is 0.7 (Cortina, 1993). All multi-item variables satisfied this (See Table 3).

As well as the testing phase described earlier, validity was assessed using construct validity (Hair, Babin, Money, \& Samouel, 2003), in particular convergent validity. This uses the correlation between two constructs to show they are potentially measuring the same concept (Trochim \& Donnelly, 2007). The correlations are significant for all pairs of items except two (out of 131 pairs), namely cwc1-cwc5 and qrks1-qrks5, which provides sufficient evidence of convergent validity.

Additionally, a non-response bias test was performed, by comparing the answers of the group of early respondents to the email invitation with those of a second group who only responded after a second invitation to participate in the survey. This second group can be regarded as more representative of nonrespondents (Lambert \& Harrington, 1990). The results indicate that just two of the 53 items had a significant mean difference between the two groups, thus it is possible to infer the absence of non-response bias.

The ANOVA technique was used to examine whether the variable means and variances differed between categories of the four demographic variables (RM area, RM process, time in position, $\mathrm{RM}$ experience). The results of the Levene test indicated that the hypothesis of equal variances was accepted for all variables and all the groups (Table 4). The Tukey test for equal means shows that two variables had a significant mean difference for just one pair of categories in each case. It was thus judged reasonable to aggregate all categories together as a first step.

Each hypothesis was tested in the form of the null hypothesis that there was no association between the variables. The minimum level of significance used was $p=0.05$ throughout.

The first step was to consider the Spearman correlations, as shown in Table 5. The two dependent variables show no significant correlation $(\rho=0.13)$. This justifies treating them as two different RM concepts in the analysis.

For the quality of risk control ( $q r c$ ), all eight correlation coefficients with the independent variables are highly significant and positive. However, only four of the independent variables ( $p q c, i i s, q r k s, c w c)$ are significantly correlated with perm; it is noticeable that the non-significant correlations are with the four technology variables.

Since all the independent variables show significant positive correlations with each other except the pairs $p q c-i s i$ and iis-isi, it was appropriate to use stepwise regression rather than simple correlation to test the hypotheses. None of the correlations between the independent variables is above 0.7 which is the threshold (Hair et al., 2003) to indicate multicollinearity.

\section{Multivariate Analysis: Regression Diagnostic}

The quality of fit of the regression models was judged by the value of R-squared and by power analysis (Cohen, Cohen, West, \& Aiken, 2003). 
Table 4. Analysis of variance tests

\begin{tabular}{|c|c|c|c|c|}
\hline \multicolumn{5}{|c|}{ Anova F-test Tukey -Test Equal Means } \\
\hline p-value & rmarea & rmprocess & timeposition & rmexperience \\
\hline isi & 0.895 & 0.321 & 0.400 & 0.907 \\
cwc & 0.716 & 0.019 & 0.206 & 0.899 \\
qrks & 0.490 & 0.024 & 0.323 & 0.356 \\
qrc & 0.672 & 0.576 & 0.405 & 0.293 \\
misf & 0.622 & 0.178 & 0.313 & 0.643 \\
nccp & 0.777 & 0.084 & 0.460 & 0.286 \\
pqc & 0.962 & 0.110 & 0.052 & 0.045 \\
iis & 0.993 & 0.083 & 0.306 & 0.953 \\
wcf & 0.933 & 0.305 & 0.259 & 0.372 \\
perm & 0.278 & 0.585 & 0.573 & 0.350 \\
\hline
\end{tabular}

Significance level $p=0.05$

QRKS differences between groups 1 and 6

PQC difference groups 1 and 4

\begin{tabular}{|c|c|c|c|c|}
\hline \multicolumn{5}{|c|}{ Anova F-Test Levene test Equal Variances } \\
\hline p-value & rmarea & rmprocess & timeposit & rmexperience \\
\hline cwc & 0.918 & 0.517 & 0.769 & 0.984 \\
isi & 0.908 & 0.198 & 0.310 & 0.442 \\
qrks & 0.829 & 0.934 & 0.593 & 0.457 \\
qrc & 0.794 & 0.842 & 0.799 & 0.742 \\
misf & 0.610 & 0.899 & 0.880 & 0.203 \\
nccp & 0.728 & 0.278 & 0.426 & 0.281 \\
pqc & 0.828 & 0.170 & 0.301 & 0.175 \\
iis & 0.450 & 0.253 & 0.677 & 0.452 \\
wcf & 0.888 & 0.547 & 0.298 & 0.829 \\
perm & 0.305 & 0.919 & 0.667 & 0.583 \\
\hline
\end{tabular}

Significance level $p=0.05$

The power threshold considered as sufficient is 0.8 (Murphy \& Myors, 1998).

The regression models used one dependent and eight independent variables in each case. Two different models were analysed, one for each dependent variable, identified here as the QRC and PERM models. Inspection showed there were no curvilinear patterns that would indicate a non-linear relationship between independent variables and dependent variable for either model.

The White test (Pindyck \& Rubinfeld, 1998) for the two models was applied and the homoscedasticity assumption is accepted at $p=0.05$. Neither model has problems with autocorrelation. For the QRC model the Durbin-Watson 
Table 5. Spearman correlation coefficients

\begin{tabular}{|c|c|c|c|c|c|c|c|c|c|c|}
\hline \multicolumn{11}{|c|}{$\begin{array}{c}\text { Spearman Correlation Coefficients, } \mathrm{N}=121 \\
\text { Prob }>|\mathbf{r}| \text { under } \mathrm{H} 0: \text { Rho }=0\end{array}$} \\
\hline & cwc & $p q c$ & iis & qrks & misf & wcf & isi & nсcp & qrc & perm \\
\hline cwc & 1 & $0.53522^{* * *}$ & $0.44956^{* * * *}$ & $0.64117^{* * *}$ & $0.49971^{* * *}$ & $0.47761^{* * *}$ & $0.37246^{* * *}$ & $0.68887^{* * *}$ & $0.61797^{* * *}$ & $0.18137^{*}$ \\
\hline pqc & $0.53522^{* * *}$ & 1 & $0.53892^{* * *}$ & $0.57959 * * *$ & $0.41088^{* * *}$ & $0.28794 * * *$ & 0.10402 & $0.45073^{* * *}$ & $0.53377^{* * *}$ & $0.27389 * *$ \\
\hline iis & $0.44956^{* * *}$ & $0.53892^{* * *}$ & 1 & $0.43134^{* * *}$ & $0.42321 * * *$ & $0.22159 *$ & 0.14778 & $0.39406 * * *$ & $0.40347^{* * *}$ & $0.25069 * *$ \\
\hline qrks & $0.64117^{* * *}$ & $0.57959^{* * *}$ & $0.43134 * * *$ & 1 & $0.56558^{* * *}$ & $0.36763^{* * *}$ & $0.23601^{* *}$ & $0.55738^{* * *}$ & $0.64337^{* * *}$ & $0.20829 *$ \\
\hline misf & $0.49971 * * *$ & $0.41088^{* * *}$ & $0.42321 * * *$ & $0.56558^{* * *}$ & 1 & $0.59586^{* * *}$ & $0.38091^{* * *}$ & $0.55309^{* * *}$ & $0.57992^{* * *}$ & 0.08741 \\
\hline wcf & $0.47761 * * *$ & $0.28794 * * *$ & $0.22159 *$ & $0.36763^{* * *}$ & $0.59586 * * *$ & 1 & $0.50363^{* * *}$ & $0.49624 * * *$ & $0.53834 * * *$ & -0.05781 \\
\hline isi & $0.37246^{* * *}$ & 0.10402 & 0.14778 & $0.23601^{* *}$ & $0.38091^{* * *}$ & $0.50363^{* * *}$ & 1 & $0.39048^{* * *}$ & $0.38709^{* * *}$ & -0.14987 \\
\hline nccp & $0.68887^{* * *}$ & $0.45073^{* * *}$ & $0.39406 * * *$ & $0.55738^{* * *}$ & $0.55309 * * *$ & $0.49624 * * *$ & $0.39048^{* * *}$ & 1 & $0.51467^{* * *}$ & 0.01827 \\
\hline qrc & $0.61797 * * *$ & $0.53377^{* * *}$ & $0.40347 * * *$ & $0.64337 * * *$ & $0.57992^{* * *}$ & $0.53834^{* * *}$ & $0.38709^{* * *}$ & $0.51467^{* * *}$ & 1 & 0.1285 \\
\hline perm & $0.18137^{*}$ & $0.27389 * *$ & $0.25069 * *$ & $0.20829 *$ & 0.08741 & -0.05781 & -0.14987 & 0.01827 & 0.1285 & 1 \\
\hline
\end{tabular}

test statistic is 1.903 and that for the PERM model is 2.112 , both in the ranges that indicate independence (Pindyck \& Rubinfeld, 1998).

The graphs of the residuals by variable in the QRC model (omitted here for reasons of space) show that the distribution of points is symmetric relative to the mean of the $\operatorname{qrc}$ variable and so do not suggest the need to transform variables. The residuals and quantile plots show no evidence of non-normality or skewness.

Additionally, the standardized predicted and residuals plot shows $93 \%$ of the cases are inside the interval $(-2,2)$ specified by Hair et al. (2003) suggesting normality as well. The analysis thus confirms that the normality hypothesis for the QRC residuals can be accepted.

A similar review of the PERM residuals shows, in the histogram and in the Q-Q and probability plots, one point that is an outlier. Inspection of the original data showed that this record comprises responses of 1 on the Likert scale to all the items comprising the perm variable. No other record included a response of 1 for any item for this variable. When including this outlier the tests of normality are not passed. It seems reasonable to conclude this respondent does not believe ERM is of any value at all, irrespective of any KM influence.

After removing this outlier, an acceptable fit to the normal distribution is found. The proportion of values outside the interval $(-2,2)$ is less than $5 \%$ (5 points out of 120$)$. Additionally, the Kolmogorov-Smirnov test indicates that the null hypothesis cannot be rejected at 5\%. Thus the normality hypothesis for the PERM residuals can be accepted for the reduced data set.

Collinearity and multicollinearity were tested and there is no indication of collinearity. According to Hair et al. (2003) values of Variance Inflation Factor greater than 10 or condition indices with a value over 30 indicate multicollinearity. Neither model exceeds the stated values.

\section{RESULTS}

\section{QRC Model}

The application of stepwise regression brought into the model four variables: the perceived quality of risk knowledge sharing (qrks), web channel functionality ( $w c f)$, perceived quality of risk communication among people ( $p q c)$, and risk management information system functionality (misf) (See Table 6). The final stepwise regression model has R-squared of 0.5916 and a power of 1 .

Four of the eight hypotheses relating to this model are thus supported. From the people variables group, one variable, the perceived quality of communication among people is positively 
Table 6. Stepwise regression results for QRC model, perceived quality of risk control

\begin{tabular}{|c|c|c|c|c|c|}
\hline \multicolumn{6}{|c|}{$\begin{array}{l}\text { Stepwise Selection: Step } 1 \\
\text { Variable qrks Entered: } R \text {-Square }=0.4177 \text { and } C(p)=50.1031\end{array}$} \\
\hline \multicolumn{6}{|c|}{ Analysis of Variance } \\
\hline Source & DF & \begin{tabular}{|l|} 
Sum of \\
Squares
\end{tabular} & $\begin{array}{l}\text { Mean } \\
\text { Square }\end{array}$ & F Value & $\mathrm{Pr}>\mathrm{F}$ \\
\hline $\begin{array}{c}\text { Model } \\
\text { Error } \\
\text { Corrected Total }\end{array}$ & $\begin{array}{c}1 \\
119 \\
120 \\
\end{array}$ & $\begin{array}{l}802.6062 \\
1118.698 \\
1921.304\end{array}$ & $\begin{array}{c}802.60616 \\
9.40082\end{array}$ & 85.38 & $<.0001$ \\
\hline Variable & $\begin{array}{c}\text { Parameter } \\
\text { Estimate }\end{array}$ & \begin{tabular}{|c|} 
Standard \\
Error \\
\end{tabular} & Type II SS & F Value & $\operatorname{Pr}>\mathrm{F}$ \\
\hline $\begin{array}{l}\text { Intercept } \\
\text { qrks }\end{array}$ & $\begin{array}{r}-4.20 \mathrm{E}-16 \\
0.70383\end{array}$ & $\begin{array}{l}0.27873 \\
0.07617\end{array}$ & $\begin{array}{r}2.14 \mathrm{E}-29 \\
802.60616\end{array}$ & $\begin{array}{r}0 \\
85.38\end{array}$ & $<.0001$ \\
\hline
\end{tabular}

\begin{tabular}{|c|c|c|c|c|c|}
\hline \multicolumn{6}{|c|}{ Stepwise Selection: Step 2 } \\
Variable wcf Entered: R-Square $=0.5363$ and C $(\mathrm{p})=18.0816$ \\
\hline \multicolumn{6}{|c|}{ Analysis of Variance } \\
\hline Source & DF & $\begin{array}{c}\text { Sum of } \\
\text { Squares }\end{array}$ & $\begin{array}{c}\text { Mean } \\
\text { Square }\end{array}$ & F Value & $\mathrm{Pr}>\mathrm{F}$ \\
\hline Model & 2 & 1030.368 & 515.18419 & 68.23 & $<.0001$ \\
Error & 118 & 890.9358 & 7.5503 & & \\
Corrected Total & 120 & 1921.304 & & & \\
\hline Variable & Parameter & Standard & Type II SS & $\mathrm{F}$ Value & $\mathrm{Pr}>\mathrm{F}$ \\
\hline \multicolumn{7}{|c|}{ Estimate } & Error \\
\hline Intercept & $-1.10 \mathrm{E}-15$ & 0.2498 & $1.45 \mathrm{E}-28$ & 0 & 1 \\
qrks & 0.53864 & 0.0746 & 393.65442 & 52.14 & $<.0001$ \\
wcf & 0.29875 & 0.05439 & 227.76222 & 30.17 & $<.0001$ \\
\hline
\end{tabular}

\begin{tabular}{|c|c|c|c|c|c|}
\hline \multicolumn{6}{|l|}{ Stepwise Selection: Step 3 } \\
Variable pqc Entered: R-Square $=0.5724$ and C $(\mathrm{p})=9.7210$ \\
\hline \multicolumn{6}{|c|}{ Analysis of Variance } \\
\hline Source & DF & $\begin{array}{c}\text { Sum of } \\
\text { Squares }\end{array}$ & $\begin{array}{c}\text { Mean } \\
\text { Square }\end{array}$ & F Value & $\mathrm{Pr}>\mathrm{F}$ \\
\hline Model & 3 & 1099.729 & 366.57628 & 52.2 & $<.0001$ \\
Error & 117 & 821.5754 & 7.02201 & & \\
Corrected Total & 120 & 1921.304 & & & \\
\hline Variable & Parameter & Standard & Type II SS & F Value & $\mathrm{Pr}>\mathrm{F}$ \\
& Estimate & Error & & & \\
\hline Intercept & $-1.16 \mathrm{E}-15$ & 0.2409 & $1.64 \mathrm{E}-28$ & 0 & 1 \\
qrks & 0.40652 & 0.08332 & 167.14734 & 23.8 & $<.0001$ \\
pqc & 0.22592 & 0.07188 & 69.36046 & 9.88 & 0.0021 \\
wcf & 0.27642 & 0.05293 & 191.48362 & 27.27 & $<.0001$ \\
\hline
\end{tabular}

\begin{tabular}{|c|c|c|c|c|c|}
\hline \multicolumn{6}{|c|}{$\begin{array}{l}\text { Stepwise Selection: Step } 4 \\
\text { Variable misf Entered: } R \text {-Square }=0.5916 \text { and } C(p)=6.2135\end{array}$} \\
\hline \multicolumn{6}{|c|}{$\begin{array}{l}\text { Analysis of Variance } \\
\end{array}$} \\
\hline Source & DF & $\begin{array}{l}\text { Sum of } \\
\text { Squares }\end{array}$ & $\begin{array}{c}\text { Mean } \\
\text { Square }\end{array}$ & F Value & $\mathrm{Pr}>\mathrm{F}$ \\
\hline Model & 4 & 1136.6 & 284.14991 & 42 & $<.0001$ \\
\hline Error & 116 & 784.7045 & 6.76469 & & \\
\hline Corrected Total & 120 & 1921.304 & & & \\
\hline Variable & $\begin{array}{c}\text { Parameter } \\
\text { Estimate }\end{array}$ & $\begin{array}{c}\text { Standard } \\
\text { Error }\end{array}$ & Type II SS & F Value & $\mathrm{Pr}>\mathrm{F}$ \\
\hline Intercept & $-1.34 \mathrm{E}-15$ & 0.23645 & $2.18 \mathrm{E}-28$ & 0 & 1 \\
\hline qrks & 0.31323 & 0.09102 & 80.11152 & 11.84 & 0.0008 \\
\hline misf & 0.18689 & 0.08005 & 36.87081 & 5.45 & 0.0213 \\
\hline pqc & 0.22441 & 0.07056 & 68.42698 & 10.12 & 0.0019 \\
\hline wcf & 0.21834 & 0.05761 & 97.1789 & 14.37 & 0.0002 \\
\hline
\end{tabular}

\begin{tabular}{|c|c|c|c|c|c|c|c|c|c|}
\hline \multicolumn{9}{|c|}{ Summary of Stepwise Selection } \\
\hline Step & $\begin{array}{c}\text { Variable } \\
\text { Entered }\end{array}$ & $\begin{array}{c}\text { Variable } \\
\text { Removed }\end{array}$ & Label & $\begin{array}{c}\text { Number } \\
\text { Vars In }\end{array}$ & $\begin{array}{c}\text { Partial } \\
\text { R-Square }\end{array}$ & $\begin{array}{c}\text { Model } \\
\text { R-Square }\end{array}$ & C(p) & F Value & Pr > F \\
\hline 1 & qrks & & qrks & 1 & 0.4177 & 0.4177 & 50.1031 & 85.38 & $<.0001$ \\
2 & wcf & & wcf & 2 & 0.1185 & 0.5363 & 18.0816 & 30.17 & $<.0001$ \\
3 & pqc & & pqc & 3 & 0.0361 & 0.5724 & 9.721 & 9.88 & 0.0021 \\
4 & misf & & misf & 4 & 0.0192 & 0.5916 & 6.2135 & 5.45 & 0.0213 \\
\hline
\end{tabular}

associated with the perceived quality of risk control $(\mathrm{H} 2 \mathrm{a})$; the process variable perceived quality of risk knowledge sharing is positively associated with perceived quality of risk control (H4a); and from the technology variables, the risk management information system functionality (H5a) and the web channel functionality (H6a) are each positively associated with the perceived quality of risk control. Table 7 summarises the results of the QRC model.

\section{PERM Model}

The only variable that entered the stepwise regression model was the perceived quality of risk communication among people ( $p q c)$ and no other variables were significant (see Table 8 ). The model has a low R-squared value of 0.09 .
Therefore, the results indicate the existence of a weak relationship (Golderberger, 1978; Newman \& Newman, 2000). Given the low $\mathrm{R}$-squared value, the power of the model was calculated: the value of 0.65 is smaller than the threshold of 0.8 recommended. Therefore, the model's capacity to describe the relationships of the variables is not sufficient to accept hypothesis $\mathrm{H} 2 \mathrm{~b}$, and so none of the hypotheses $\mathrm{H} 1 \mathrm{~b}-\mathrm{H} 8 \mathrm{~b}$ are supported.

\section{DISCUSSION AND IMPLICATIONS}

Four KM variables were found to be significantly associated with the perceived quality of risk control: perceived quality of communica- 
Table 7. Summary of hypothesis tests for QRC model

\begin{tabular}{|c|c|}
\hline Hypotheses & Results \\
\hline \multicolumn{2}{|c|}{ People } \\
\hline $\begin{array}{l}\text { H1a: Organizational capacity for work coordination } \\
(c w c) \text { is positively associated with the perceived quality } \\
\text { of risk control }(q r c)\end{array}$ & Not Supported \\
\hline $\begin{array}{l}\text { H2a: The perceived quality of communication among } \\
\text { people }(p q c) \text { is positively associated with perceived } \\
\text { quality of risk control }(q r c)\end{array}$ & Supported \\
\hline $\begin{array}{l}\text { H3a: Perceived quality of people interactions in the } \\
\text { ERMIS design (iis) is positively associated with the } \\
\text { perceived quality of risk control( } q r c)\end{array}$ & Not Supported \\
\hline \multicolumn{2}{|c|}{ Process } \\
\hline $\begin{array}{l}\text { H4a: The perceived quality of risk knowledge sharing } \\
(q r k s) \text { is positively associated with the perceived quality } \\
\text { of risk control }(q r c)\end{array}$ & Supported \\
\hline \multicolumn{2}{|c|}{ Technology } \\
\hline $\begin{array}{l}\text { H5a: The risk management information system } \\
\text { functionality (misf) is positively associated with the } \\
\text { perceived quality of risk control(qrc) }\end{array}$ & Supported \\
\hline $\begin{array}{l}\text { H6a: The web channel functionality }(w c f) \text { is positively } \\
\text { associated with the perceived quality of risk } \\
\text { control }(q r c)\end{array}$ & Supported \\
\hline $\begin{array}{l}\text { H7a: The perceived integration of the information } \\
\text { systems (isi) is positively associated with the perceived } \\
\text { quality of risk control }(q r c)\end{array}$ & Not Supported \\
\hline $\begin{array}{l}\text { H8a: The quality of the network capacity for connecting } \\
\text { people }(n c c p) \text { is positively associated with the } \\
\text { perceived quality of risk control( } q r c)\end{array}$ & Not Supported \\
\hline
\end{tabular}

Table 8. Stepwise regression results for PERMmodel, perceived value of enterprise riskmanagement

\begin{tabular}{|l|l|l|l|l|l|l|}
\hline Root MSE & 6.3355 & R-Square & 0.0903 \\
\hline Dependent Mean & 0.2568 & Adj. R-Square & 0.0826 \\
\hline Coefficient Variance & 2466.7 & & \multicolumn{2}{c|}{ Pr>F } \\
\hline \multicolumn{7}{|c|}{ Analysis of Variance } \\
\hline \multicolumn{7}{|c|}{ Source }
\end{tabular}


tion among people ( $p q c, \mathrm{H} 2 \mathrm{a})$, perceived quality of risk knowledge sharing (qrks, H4a), risk management information systems functionality (misf, H5a) and web channel functionality (wcf, H6a). Risk knowledge sharing and communication among people may be described as social factors, and indeed perceived quality of risk knowledge sharing ( $q r k s)$ is the most influential variable in the perceived quality of risk control model.

Risk knowledge sharing is an activity that financial institutions will always need to deal with. For example, what is done in one area may be an input in another, and there are multiple stakeholders involved. If a "silo organization" obstructs risk knowledge sharing, our findings suggest risk control may be adversely affected.

The support for hypothesis H2a complements the findings of Julibert (2008) and Waldvogel and Whelan (2008) that without communication no $\mathrm{KM}$ is possible and that communication and good risk learning support collaboration.

Given the lack of support for H8a, the effect of the quality of the network capacity for connecting people, this suggests that people prefer informal communication mechanisms to formal ones. Thus in RM practice, improving social factors, for example by creating spaces for better communication among groups, and improving messages and other means of communication may lead to better risk knowledge sharing, confirming the findings of Bosua and Scheepers (2007) in other sectors. This in turn should contribute positively to the quality of risk control.

As support for risk modelling analysis and work flow (Crouhy et al., 2001; Hormozi $\&$ Giles, 2004), better risk management information systems functionality is likely to have a positive effect on risk control.

For the significant association of web channel functionality, several authors (e.g. Desouza \& Awazu, 2005; M. Jennex, 2005, 2006; Spies et al., 2005) have indicated that an effective intranet enables an integrated technical infrastructure in order to disseminate knowledge and to support KM processes. The intranet, in financial institutions, provides access to different components of the organization's knowledge and in some cases, to operational tools. RM intranet functionality enhancements, according to the results, are likely to add value to risk control.

\section{Interpreting the PERM Results}

The perceived value of ERM implementation is weakly associated with the KM variable perceived quality of communication among people $(p q c)$ and is not associated with the other KM variables studied. This means that efforts in improving $\mathrm{KM}$ are not perceived as having the same organization-wide effect in implementing ERM as they have in the more local problem of controlling operational risk.

To explain this, consider the demographic characteristics of our sample, especially time in the position and risk management experience: $94 \%$ of responses came from people with less than ten years in their current position, and $73 \%$ from those with less than ten years of experience. This combination of short time in a position and low experience (many staff spend their entire working careers in RM) indicates a potential lack of an holistic view of the RM function, because there is a reduced exposure to the whole spectrum of RM work; particularly as most junior RM roles are very specialized and lack of seniority potentially restricts access to information and decisions. Francis and Paladino (2008) pointed out that the best practices of ERM require a high degree of participation and involvement in strategic actions. Thus it may be that the population would simply not be able to perceive any benefits that existed: indeed, the outlier response removed from this model can be argued to have come from someone who did not perceive ERM to be of any value at all.

\section{CONCLUSION}

Our study has examined eight KM constructs associated with knowledge sharing (three relating to people, one relating to process and four relating to technology) and two RM constructs 
(the perceived quality of risk control and the perceived value of ERM implementation) in the financial services sector. A survey obtained responses from 121 risk management staff in financial institutions. The first step towards our research aim was the identification of these ten variables (eight KM and two RM) and the construction of items and scales for them. These are a contribution to future studies in the field in themselves, given the results of the pilot testing and the Cronbach alpha values for the reliability of the scales.

The overall aim of this research was to study how KM concepts may help improve RM, and help to turn it into true ERM. Specifically, we aimed to identify KM variables associated with knowledge sharing that can influence the perceived quality of risk control and the perceived value of ERM implementation. Eight pairs of hypotheses were tested by stepwise regression. The findings showed that four of the eight variables analysed have a significant positive association overall with the perceived quality of risk control. These are: one people variable (perceived quality of communication among people), the sole process variable (perceived quality of risk knowledge sharing) and two technology variables (risk management information system functionality and web channel functionality).

The perceived quality of risk knowledge sharing accounted for by far the largest part of the variation $(31.3 \%)$ in the dependent variable perceived quality of risk control. When risk actions, decisions and the experiences that people have in dealing with different risks are shared between different RM groups, they develop awareness and warning signals as inputs to the risk control process. According to our findings, this means that actions to improve risk knowledge sharing are likely to have the most positive effects on the perceived quality of risk control.

The only KM variable associated with the perceived value of ERM implementation (PERM) was the perceived quality of communication among people; however, the low
R-squared (0.09) and power(0.65) values make this a tenuous relationship. Thus either KM has little influence on the value of ERM implementation, or RM workers are not able to perceive that it does. Two possible explanations to support the latter are: (a) that organizational silos still prevail, and local operational risk control is the main concern, while overall ERM success, for most people, remains someone else's problem; and/or (b) that the majority of relatively junior and inexperienced staff among the respondents are not able to take the holistic view that ERM requires and do not know how valuable or otherwise ERM implementation is in their organization. Padova and Scarso (2012) have recently described similar tensions between local and global knowledge management issues even in an organization as experienced in $\mathrm{KM}$ as Ernst \& Young. It is also very relevant to note the comments of Zack, McKeen, and Singh (2009) that "[a] gap exists between KM practices that firms believe to be important and those that were directly related to organizational performance."

The research has thus provided evidence that aligning $\mathrm{KM}$ and $\mathrm{RM}$ processes should achieve better RM results in risk control. Specifically, recalling the concept of financial institutions as risk and knowledge organizations, the results indicate not only that better interpretation of the meaning of RM information is needed, but also that organizational RM knowledge needs to be managed better (Marshall et al., 1996) through better risk knowledge sharing, better risk management information systems functionality, better communication among people and better web channel functionality.

There are some limitations to the research process. Our study is based on perceptions of the RM process performance rather than the RM outcome performance. Improvement in the representation of senior staff in the sample could be secured through a stratification according to organizational levels or the number of years of experience. The geographical distribution of the respondents, skewed toward North America, may be a factor influencing results because the 
degree of maturity in RM might be different in different countries. The period when the data were collected was at the beginning of the global financial crisis, which may have coloured the responses. Finally, the size of the institution in which the RM employee works might affect the level of development and sophistication in RM practice.

This study also raises questions for new research. One is related to the concept of information system integration, which unexpectedly revealed a negative association with the perceived value of ERM implementation, albeit not a statistically significant one. Further work is also needed relating to possible differences between global, top-down business needs for KM and local, bottom-up user perceptions, and how this might affect the management of risk knowledge. Equally, RMneeds studies directed to identifying the "soft" part of risk management and its influence in the decision making process and how to grow the capacity for people to develop these activities in a better and more reliable organizational environment. Finally, objective proxy measures of RM performance could be used in studies of specific sectors, such as commercial lending.

\section{REFERENCES}

Aaker, D., Day, G., \& Kumar, V. (1998). Marketing Research. New York: John Wiley and Sons.

Alavi, M., \& Leidner, D. (2001). Review: Knowledge management and knowledge management systems: conceptual foundations and research issues. Management Information Systems Quarterly, 25(1), 107-136. doi: $10.2307 / 3250961$

Alfares, H., \& Duffuaa, S. (2008). Assigning cardinal weights in multi-criteria decision making. Journal of Multi-Criteria Decision Analysis, 15(5-6), 125-133. doi:10.1002/mcda.420

Babbie, E. (1998). The Practice of Social Research. Belmont, CA: Wadsworth Publishing Co.

Banham, R. (2004). Enterprising views of risk management. Journal of Accountancy, 197(6), 65-72.
Beasley, M., Bronson, B., \& Hancock, B. (2009). ERM: Opportunities for improvement. Journal of Accountancy, 208(3), 175-179.

Bohrnstedt, G., \& Knoke, D. (1982). Statistics for Social Data Analysis. Itasco, IL: F.E. Peacock Publishers.

Bosua, R., \& Scheepers, R. (2007). Towards a model to explain knowledge sharing in complex organizational environments. Knowledge Management Research and Practice, 5(2), 93-109. doi:10.1057/ palgrave.kmrp. 8500131

Brown, B. (2001). Step by step enterprise risk management. Risk Management, 48(9), 43-50.

Champion, D. (2009). Managing risk in the new world. Harvard Business Review, 87(10), 69-75.

Cohen, J., Cohen, P., West, S. G., \& Aiken, L. S. (2003). Applied Multiple Regression/Correlation Analysis for the Behavioral Sciences. Mahwah, NJ: Lawrence Erlbaum Associates.

Cortina, J. (1993). What is coefficient alpha? an examination of theory and applications. The Journal of Applied Psychology, 78(1), 98-104. doi:10.1037/0021-9010.78.1.98

Crouhy, M., Galai, D., \& Mark, R. (2001). Risk Management. New York: McGraw Hill.

Cumming, C., \& Hirtle, B. (2001). The challenges of risk management in diversified financial companies. Federal Reserve Bank of New York Economic Policy Review, 4(3), 1-17.

Davenport, T., \& Prusak, L. (1998). Working Knowledge. Boston, MA: Harvard Business School Press.

Desouza, K., \& Awazu, Y. (2005). Engaged Knowledge Management: Engagement with new realities. Basingstoke, UK: Palgrave Macmillan. doi:10.1057/9780230006072

Dickinson, G. (2001). Enterprise Risk Management: Its origins and conceptual foundation. The Geneva Papers on Risk and Insurance, 26(3), 360-366. doi:10.1111/1468-0440.00121

Earl, M. (2001). Knowledge management strategies: Toward a taxonomy. Journal of Management Information Systems, 18(1), 215-233.

Edwards, J. S. (2009). Business processes and knowledge management. In M. Khosrow-Pour (Ed.), Encyclopedia of Information Science and Technology (2nd ed., Vol. I, pp. 471-476). Hershey, PA: IGI Global. 
Fourie, L., \& Shilawa, J. (2004). The value of concept maps for knowledge management in the banking and insurance industry: A German case study, Concept Maps: Theory, Methodology, Technology: Proceedings of the First International Conference on Concept Mapping. Pamplona, Spain.

Francis, S., \& Paladino, B. (2008). Enterprise Risk Management: A best practice approach. Journal of Corporate Accounting \& Finance, 19(3), 19-33. doi:10.1002/jcaf.20382

Golderberger,A.(1978). Topics in Regression Analysis. New York: McMillan.

Hair, J., Babin, B., Money, A., \& Samouel, P. (2003). Essentials of Business Research Methods. New York: John Wiley and Sons.

Heisig, P. (2009). Harmonisation of knowledge management. Journal of Knowledge Management, 13(4), 4-31. doi:10.1108/13673270910971798

Hobday, M., Davies, A., \& Prencipe, A. (2005). Systems integration: A core capability of the modern corporation. Industrial and Corporate Change, 14(6), 1109-1143. doi:10.1093/icc/dth080

Hormozi, A., \& Giles, S. (2004). Data mining a competitive weapon for banking and retail industries. Information Systems Management, 21(2), 62-71. doi:10.1201/1078/44118.21.2.20040301/80423.9

Hsu, C., Backhouse, J., \& Silva, L. (2013). Institutionalizing operational risk management: An empirical study. Journal of Information Technology. doi:10.1057/jit.2013.15

Jennex, M. (2005). Internet Support for Knowledge Management Systems. In M. Khosrow-Pour (Ed.), Encyclopedia of Information Science and Technology (pp. 1640-1644). Hershey, PA: Idea Group. doi:10.4018/978-1-59140-553-5.ch289

Jennex, M. (2006). Knowledge Management System Success Factors. In D. Schwartz (Ed.), Encyclopedia of Knowledge Management (pp.436-441). Hershey, PA: Idea Group Reference.

Jennex, M. E., \& Zyngier, S. (2007). Security as a contributor to knowledge management success. Information Systems Frontiers, 9(5), 493-504. doi:10.1007/s10796-007-9053-4

Julibert, S. (2008). Employee attitudes to information sharing: A case study at the European Central Bank. Records Management Journal, 18(3), 194-204. doi:10.1108/09565690810916447
Lam, J. (2003). Enterprise Risk Management: from Incentives to Controls. Hoboken, NJ: John Wiley \& Sons.

Lambert, D., \& Harrington, T. (1990). Measuring nonresponse bias in customer service mail surveys. Journal of Business Logistics, 11(2), 5-25.

Lee, S., \& Lam, W. (2007). Application Integration: Pilot Project to Implement a Financial Portfolio System in a Korean Bank. In W. Lam, \& V. Shankararaman (Eds.), Enterprise Architecture and Integration: Methods, Implementation and Technologies (pp. 273-283). Hershey, PA: IGI Global. doi:10.4018/9781-59140-887-1.ch016

Lehaney, B., Clarke, S., Coakes, E., \& Jack, G. (2004). Beyond Knowledge Management. Hershey, PA: Idea Group Publishing.

Levine, R. (2004). Risk management systems: Understanding the need. Information Systems Management, 21(2), 31-37. doi:10.1201/1078/44118.21.2. $20040301 / 80419.5$

Majchrzak, A., Beath, C., \& Lim, R. (2005). Managing client dialogues during information systems design to facilitate client learning. Management Information Systems Quarterly, 29(4), 653-672.

Marshall, C., Prusak, L., \& Shpilberg, D. (1996). Financial risk and the need for superior knowledge management. California Management Review, 38(3), 77-101. doi:10.2307/41165844

Massingham,P.(2010).Knowledgerisk management: A framework. Journal of Knowledge Management, 14(3), 464-485. doi:10.1108/13673271011050166

McNally, J. S. (2013). The 2013 COSO Framework \& SOX Compliance. Strategic Finance, (June 2013). http://www.coso.org/documents/COSO\%20McNallyTransition $\% 20$ Article-Final $\% 20$ COSO $\% 20$ Version\%20Proof_5-31-13.pdf

Meulbroek, L. (2002). The promise and challenge of integrated risk management. Risk Management \& Insurance Review, 5(1), 55-66. doi:10.1111/10981616.00006

Murphy, K., \& Myors, B. (1998). Statistical Power Analysis. Mahwah, NJ: Lawrence Erlbaum Associates Publishers.

Newman, I., \& Newman, C. (2000). A discussion of low r-squares: Concerns and uses. Educational Research Quarterly, 24(2), 3-9. 
Nonaka, I. (1991). The Knowledge Creating Company. Harvard Business Review, 69(6), 96-104.

O’Brien, J. (1996). Management Information systems. Chicago: Irwin.

Padova, A., \& Scarso, E. (2012). Managing large amounts of knowledge objects: Cognitive and organisational problems. Knowledge Management Research \& Practice, 10(4), 287-295. doi:10.1057/ kmrp.2012.7

Pindyck, R., \& Rubinfeld, D. (1998). Econometric Models and Economic Forecasts. Boston, MA: Irwin-McGraw Hill.

Ribière, V., \& Walter, C. (2013). 10 years of KM theory and practices. Knowledge Management Research \& Practice, 11(1), 4-9. doi:10.1057/ kmrp.2012.64

Rodriguez, E., \& Edwards, J. S. (2010). People, technology, processes and risk knowledge sharing. Electronic Journal of Knowledge Management, 8(1), 139-150.

Shariq, S., \& Vendelo, M. (2006). Tacit Knowledge Sharing. In D. Schwartz (Ed.), Encyclopedia of Knowledge Management (pp. 833-839). Hershey, PA: Idea Group Reference. doi:10.4018/978-159140-573-3.ch109

Shaw, D., Hall, M., Edwards, J. S., \& Baker, B. (2007). Responding to crisis through strategic knowledge management. Journal of Organizational Change Management, 20(4), 559-578. doi:10.1108/09534810710760081

Spies, M., Clayton, A. J., \& Noormohammadian, M. (2005). Knowledge management in a decentralized global financial services provider: A case study with Allianz Group. Knowledge Management Research \& Practice, 3(1), 24-36. doi:10.1057/palgrave. kmrp.8500046

Swan, J., Newell, S., Scarborough, H., \& Hislop, D. (1999). Knowledge management and innovation: Networks and networking. Journal of Knowledge Management, 3(4), 262-275. doi:10.1108/13673279910304014

Taleb, N., Goldstein, D., \& Spitznagel, M. (2009). The six mistakes executives make in risk management. Harvard Business Review, 87(10), 78-81. PMID:19968059

Te'eni, D. (2006). Organisational Communication. In D. Schwartz (Ed.), Encyclopedia of Knowledge Management (pp. 734-740). Hershey, PA: Idea Group Reference. doi:10.4018/978-1-59140-573-3.ch096
Trkman, P., \& Desouza, K. C. (2012). Knowledge risks in organizational networks: An exploratory framework. The Journal of Strategic Information Systems, 21(1),1-17.doi:10.1016/j.jsis.2011.11.001

Trochim, W., \& Donnelly, J. (2007). The Research Methods Knowledge Base. Cincinnati, OH: Atomic Dog Publishing.

Uchupalanan, K. (2000). Competition and IT-based innovation in banking services. International Journal of Innovation Management, 4(4), 455-489. doi:10.1142/S1363919600000238

Uzzi, B., \& Lancaster, R. (2003). Relational embeddedness and learning: The case of bank loan managers and their clients. Management Science, 49(4), 383-399. doi:10.1287/mnsc.49.4.383.14427

Värlander, S. (2008). The role of situated embodied interaction in the banking customer knowledge creation process. International Journal of Knowledge Management, 4(4), 62-76. doi:10.4018/ jkm.2008100104

Waldvogel,A., \& Whelan, N. (2008). Towards better financial risk learning. Journal of Risk Management in Financial Institutions, 4(4), 382-393.

Wiig, K. (1997). Knowledge management: Where did it come from and where will it go? Expert Systems with Applications, 13(1), 1-14. doi:10.1016/ S0957-4174(97)00018-3

Wiig, K. (2004). People-Focused Knowledge Management. Burlington, MA: Elsevier Butterworth Heinemann.

Zack, M., McKeen, J., \& Singh, S. (2009). Knowledge management and organizational performance: An exploratory analysis. Journal of Knowledge Management, 13(6), 392-409. doi:10.1108/13673270910997088

Zyngier, S. (2008). Risk Management: Strengthening Knowledge Management. International Journal of Knowledge Management, 4(3), 1-32. doi:10.4018/ jkm.2008070102

Zyngier, S., \& Burstein, F. (2012). Knowledge management governance: The road to continuous benefits realization. Journal of Information Technology, 27(2), 140-155. doi:10.1057/jit.2011.31

Zyngier, S., \& Venkitachalam, K. (2011). Knowledge management governance - a strategic driver. Knowledge Management Research \& Practice, 9(2), 136-150. doi:10.1057/kmrp.2011.5 


\title{
GALL FOR ARTICLES
}

\section{International Journal of Knowledge Management}

\author{
An official publication of the Information Resources Management Association
}

\begin{abstract}
MISSION:
The primary objective of the International Journal of Knowledge Management (IJKM) is to provide a comprehensive cross discipline forum for advancing the understanding of the organizational, technical, human, and cognitive issues associated with the creation, capture, transfer and use of knowledge in organizations. The secondary objective of this Journal is to share knowledge among researchers and practitioners with respect to the design, development, implementation and maintenance of effective knowledge management systems. The journal publishes high quality empirical and theoretical research covering all aspects of knowledge management. In addition to full-length research manuscripts, the journal publishes insightful research and practice notes as well as case studies from all areas of knowledge management.
\end{abstract}

\section{COVERAGE/MAJOR TOPICS:}

- Basic theories associated with knowledge creation, knowledge management, and organizational memory

- Case studies of knowledge management and organizational memory systems

- Cognitive theories of knowledge management and organizational memory

- Design of information and communication systems that facilitate knowledge transfer and sharing

- Enablers and inhibitors of knowledge sharing and knowledge transfer behaviors

- Global issues in knowledge management and organizational memory

- Issues related to the capture, storage, search, retrieval, and use of knowledge and organizational memory

- Knowledge Acquisition and Transfer Processes

- Knowledge management in small and medium enterprises

- Knowledge Management Strategy

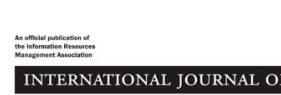

Knowledge Management

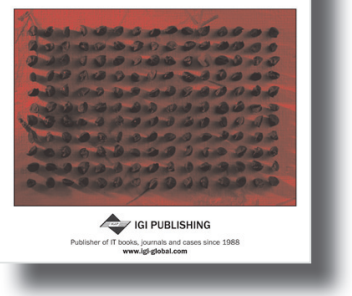

ISSN 1548-0666

eISSN1548-0658

Published quarterly
- Knowledge management training issues

- Knowledge reuse in organizations

- Knowledge transfer and sharing behaviors within emergent organizational forms such as virtual communities

- Methodologies and processes for developing knowledge management systems

- Metrics and effectiveness of knowledge management and organizational memory systems

- Organizational and economic incentive structures for knowledge sharing and use

- Organizational culture impacts on knowledge management

- Organizational Learning

- Use of semantic networks, topic maps, the Internet, digital documents, XML, taxonomies, ontologies, and other technologies to implement knowledge management systems

All inquiries regarding IJKM should be directed to the attention of:

Murray E. Jennex, Editor-in-Chief ijkm@igi-global.com

All manuscript submissions to IJKM should be sent through the online submission system: http://www.igi-global.com/authorseditors/titlesubmission/newproject.aspx

Ideas for Special Theme Issues may be submitted to the Editor-in-Chief.

Please recommend this publication to your librarian. For a convenient easy-

to-use library recommendation form, please visit: http://www.igi-global.com/IJKM 